\title{
EVALUASI DAN REFORMULASI STRATEGI PROMOSI FESTIVAL PARADE PESONA KEBANGSAAN KABUPATEN ENDE, NUSA TENGGARA TIMUR
}

\author{
Aloysius P. Langga B.T. \\ Magister Kajian Pariwisata Universitas Gadjah Mada, Indonesia \\ algonbt@gmail.com
}

\begin{abstract}
The implementation of the tourism festival event is one way to promote tourism potential. In addition to the purpose of tourism promotion, the festival is held to increase the number of tourist visits, increase local revenue, and provide economic income for the local community. Since 2015, the Ende Regency government through the Tourism Office has conducted a tourism event. The event was the "Festival Parade Pesona Kebangsaan (FPPK)". This festival has aims to promote tourist attraction objects in Ende Regency as well as to commemorate the history of the birth of Pancasila which was sparked by Bung Karno during his exile in Ende (1934-1938). "Festival Parade Pesona Kebangsaan" is not yet perfect and still needs a lot of improvement. The implementation of promotional activities and tourism promotion is also still limited to the implementation of formalities and without good preparation. The focus of this research is the evaluation and reformulation of the promotion strategy of the "Festival Parade Pesona Kebangsaan" in Ende Regency, which is divided into the identification and analysis of the factors that influence the activities of the "Festival Parade Pesona Kebangsaan", as well as the evaluation and reformulation of the promotion strategy to perfect the next program of activities. This study uses a descriptive-analytic method with a qualitative approach that aims to describe and evaluate and reformulate the promotion strategy of the "Festival Parade Pesona Kebangsaan" in Ende.
\end{abstract}

Keywords: Evaluation, Promotion, Festival, Ende.

\begin{abstract}
Abstrak
Pelaksanaan event festival pariwisata merupakan salah satu cara untuk mempromosikan potensi wisata. Selain untuk tujuan promosi wisata, festival diadakan untuk meningkatkan jumlah kunjungan wisatawan, menambah pendapatan asli daerah dan memberi pendapatan ekonomi bagi masyarakat lokal. Sejak tahun 2015, pemerintah Kabupaten Ende melalui Dinas Pariwisata sudah melakukan sebuah event pariwisata. Event tersebut ialah Festival Parade Pesona Kebangsaan (FPPK). Festival ini memiliki tujuan untuk mempromosikan objek daya tarik wisata yang ada di Kabupaten Ende sekaligus untuk mengenang sejarah lahirnya Pancasila yang dicetuskan oleh Bung Karno selama masa pembuangan di Ende (1934-1938) Pelaksanaan Festival Parade Pesona Kebangsaan belum sepenuhnya sempurna dan masih perlu banyak perbaikan. Pelaksanaan promosi kegiatan dan promosi wisata juga masih terbatas pada pelaksanaan yang formalitas dan tanpa persiapan yang baik. Fokus penelitian ini adalah evaluasi dan reformulasi strategi promosi Festival Parade Pesona Kebangsaan di Kabupaten Ende yang terbagi dalam identifikasi dan analisis faktor-faktor yang mempengaruhi kegiatan Festival Parade Pesona Kebangsaan, serta evaluasi dan reformulasi strategi promosi untuk penyempurnaan program kegiatan yang akan dilaksanakan selanjutnya. Penelitian ini menggunakan metode deskriptif analitik dengan pendekatan kualitatif yang bertujuan untuk mendeskripsikan dan mengevaluasi dan mereformulasi strategi promosi Festival Parade Pesona Kebangsaan di Kabupaten Ende.
\end{abstract}

Kata kunci: Wisata Massal, Wisata Alternatif, Warisan, Warisan Masyarakat, Warisan Pariwisata, Produk Pariwisata, Paket Wisata, Daya Tarik Bangunan

\section{A. PENDAHULUAN}

Pariwisata merupakan industri jasa yang menjanjikan dan menguntungkan. Industri pariwisata juga memberikan keuntungan bagi wilayah-wilayah yang dikunjungi atau daerah-daerah yang menjadi destinasi wisata. Hal inilah yang membuat pemerintah pusat menjadikan Provinsi Nusa Tenggara Timur (NTT) sebagai daerah unggulan baru pariwisata di kawasan Indonesia timur sejak tahun 2007. Prioritas 
pemerintah dalam pariwisata di NTT dilakukan dengan cara melakukan dan mempromosikan pariwisata lewat festival pariwisata tahunan sebagai bagian dari promosi pariwisata NTT.

Festival atau event yang menarik perhatian nasional untuk Provinsi NTT adalah Festival Parade Pesona Kebangsaan (FPPK). Event FPPK ini adalah salah satu sarana untuk mempromosikan dan mengangkat pariwisata di Kabupaten Ende. Selain untuk mempromosikan destinasi wisata di Kabupaten Ende, dan untuk mengenang kembali lahirnya Pancasila oleh di Ende. Festival ini juga ingin memperkenalkan kepada dunia bahwa Ende adalah Kota Pancasila.

Destinasi wisata di Kabupaten Ende sangat banyak. Ada wisata bahari, wisata alam dan budaya, dan wisata buatan. Akan tetapi objek daya tarik wisata ini belum sepenuhnya diperhatikan pengelolaannya sehingga belum mengalami perkembangan signifikan. Peningkatan jumlah kunjungan wisatawan di Kabupaten Ende masih belum terlalu signifikan. Oleh karena itu, untuk memperkenalkan keunggulan potensi wisata tersebut maka dibuatlah festival. Festival adalah suatu peristiwa atau kejadian penting, suatu fenomena sosial yang pada hakekatnya di jumpai dalam semua kebudayaan manusia (Jiunkpe, 1998). Event-event dan festival dilakukan demi memberitahukan, membujuk atau meningkatkan jumlah wisatawan supaya calon wisatawan mempunyai keinginan untuk datang berkunjung ke daerah yang telah dipromosikan.

Strategi promosi lewat festival pariwisata belum cukup menambah jumlah kunjungan wisatawan. Akhirnya persepsi yang muncul adalah setiap event dan festival wisata yang dilakukan hanya menghabiskan anggaran dan tidak terlalu signifikan dalam meningkatkan pendapatan daerah serta kesejahteraan ekonomi masyarakat lokal. Pelaksanaan Festival Parade Pesona Kebangsaan di kabupaten Ende membutuhkan suatu penyempurnaan. Oleh karena itu dibutuhkan evaluasi terkait kegiatan event ini. Cronbach dalam Harris (1985) menyatakan bahwa evaluasi merupakan pemeriksaan yang sistematis terhadap segala peristiwa yang terjadi sebagai akibat dilaksanakannya suatu program. Dalam hal ini lebih meninjau pengertian evaluasi program dalam konteks tujuan yaitu sebagai proses menilai sampai sejauhmana tujuan pendidikan dapat dicapai (Tayibnapis, 2000). Evaluasi adalah upaya untuk memperoleh feedback perbaikan program dan upaya menilai manfaat program dan mengambil keputusan (Lehman, 1990).

Festival Parade Pesona Kebangsaan adalah sebuah strategi promosi pariwisata yang dilakukan oleh Dinas Pariwisata Kabupaten Ende. Strategi adalah penetapan berbagai tujuan dan sasaran jangka panjang yang bersifat mendasar bagi semua organisasi yang dilanjutkan dengan penetapan rencana aktivitas dan pengalokasian sumber daya yang diperlukan guna mencapai berbagai sasaran tersebut (Fred, 2009); Seperangkat keputusan dan tindakan yang menghasilkan formulasi dan implementasi dari rencana yang didesain untuk mencapai tujuan (Pearce \& Robinson, 2008).

Promosi pariwisata adalah suatu bentuk penawaran dan pengenalan suatu produk terhadap konsumen atau pelanggan atau yang disebut dengan wisatawan. Untuk menghasilkan penjualan produk yang maksimal maka dibutuhkan promosi. Promosi merupakan bagian dari bentuk pemasaran suatu produk atau jasa kepada konsumen. Di dalam pemasaran, dikenal pula dengan bauran promosi (promotion mix). Kotler dan Keller (2009) mengartikan bauran promosi adalah paduan spesifik periklanan, promosi penjualan, hubungan masyarakat, penjualan personal, dan pemasaran langsung yang digunakan perusahaan untuk mengomunikasikan nilai pelanggan secara persuasif dan membangun hubungan pelanggan.

Menurut Kotler (1999), elemen utama dari promosi yakni seperti berikut: pertama, Personal Selling (Penjualan Perorangan) adalah bentuk komunikasi antar individu di mana tenaga penjual menginformasikan, mendidik, dan melakukan persuasi kepada calon pembeli atau membeli produk atau jasa perusahaan; Kedua, Advertising (Periklanan) adalah sebuah pengiriman pesan melalui suatu media yang dibayar sendiri oleh pemasang iklan; ketiga, Sales Promotion (Promosi Penjualan) terdiri dari semua 
kegiatan promosi yang mencoba merangsang terjadinya pembelian dalam waktu yang; keempat, Publicity (Publisitas) menggambarkan komunikasi massa, namun juga tidak seperti periklanan mengeluarkan biaya untuk waktu dan ruang beriklan.; kelima, Sponsorship Marketing (Pemasaran Sponsorships) adalah aplikasi dalam mempromosikan perusahaan atau lembaga/instansi atau salah satu merek dengan kegiatan tertentu; keenam, Point-of-purchase communication (Komunikasi Di Tempat Pembelian) melibatkan peraga, poster, tanda, dan berbagai materi lain yang didesain untuk mempengaruhi keputusan untuk membeli dalam tempat pembelian.

Beradasarkan permasalahan yang ditemukan di atas terkait strategi promosi Festival parade pesona kebangsaan maka tujuan dari penelitian ini adalah mengidentifikasi dan menganalisis faktor faktor yang mempengaruhi kunjungan wisatawan, pendapatan daerah, pengembangan pariwisata dan pendapatan masyarakat terkait kegiatan event FPPK, mengevaluasi strategi promosi wisata lewat event FPPK yang telah dilakukan oleh Dinas Pariwisata Kabupaten Ende dan memformulasikan kembali strategi dan solusi untuk penyempurnaan kegiatan event FPPK.

\section{B. METODE PENELETIAN}

Penelitian ini dilakukan di Kabupaten Ende. Evaluasi terhadap strategi promosi Festival Parade Pesona Kebangsaan Kabupaten Ende dijelaskan dengan menggunakan metode deskriptif analitik. Metode ini dipakai dan dipilih untuk menggambarkan dan menganalisis hasil penelitian terkait event tersebut. Pendekatan yang digunakan ialah pendekatan kualitatif. Tujuan dari penelitian kualitatif ini adalah untuk mendeskripsikan atau menjabarkan temuan atau fenomena, menyajikan apa adanya sesuai fakta atau temuan di lapangan (Tobing et al, 2016).

Berdasarkan fokus penelitian ini yakni evaluasi strategi promosi Festival Parade Pesona Kebangsaan maka dalam mengidentifikasi program kegiatan, menjabarkan faktor-faktor yang mempengaruhi kegiatan dan penyempurnaan kegiatan ini, peneliti memilih metode evaluasi dengan cara wawancara mendalam melalui komunikasi langsung (Yusuf, 2014) dengan berbagai nara sumber yang kompeten di bidangnya masing-masing. Penulis juga melakukan studi dokumentasi lewat catatan-catatan, gambar dan tulisan (Sugiyono, 2013:240). Peneliti juga mlakukan observasi sehingga pencatatan bersifat sistematis, logis, objektif, dan rasional terhadap berbagai macam fenomena dalam situasi yang sebenarnya, maupun situasi buatan (Kristanto, 2018).

Peneliti melakukan analisis data pada saat melakukan pengumpulan data dan setelah melakukan pengumpulan data berkaitan dengan strategi promosi wisata melalui event FPPK. Teknik analisis data yang digunakan dalam penelitian ini adalah deskriptif kualitatif. Peneliti menguraikan pemaparan hasil penelitian yang difokuskan pada kegiatan event FPPK. Data-data yang dianalisis dan diuraikan adalah data-data yang terkait dengan strategi promosi wisata melalui event FPPK. Untuk menentukan keabsahan data dalam penelitian kualitatif ini, peneliti juga melakukan triangulasi data untuk menguji kredibilitas data yang sudah diperoleh (Susanti, Damanik \& Priyambodo, 2017). Uji Triangulasi berupaya untuk mengecek kebenaran data dan membandingkan dengan data yang diperoleh dari dengan data yang diperoleh dari dengan sumber lain terkait event FPPK.

\section{HASIL PENELITIAN}

Festival Parade Pesona Kebangsaan diadakan sejak tahun 2014. Festival ini diadakan setiap tahun dengan tema khusus yakni "Pancasila Rumah Kita, Dari Ende Untuk Indonesia". Ada pun tujuan dari peaksanaan festival ini yakni: untuk membangkitkan semangat nasionalisme dengan memperkokoh nilainilai kebangsaan, untuk mengenang Ende sebagai Kota Sejarah tempat penggalian ide atau gagasan tentang nilai-nilai luhur Pancasila, untuk mewariskan nilai sejarah bangsa kepada kepada generasi muda dengan menjaga dan memelihara nilai budaya, sosial dan adat istiadat yang telah hidup dan berkembang 
dalam kehidupan masyarakat suku dan bangsa di wilayah Indonesia, untuk meningkatkan semangat gotong-royong dalam kegiatan pembangunan nasional, untuk meningkatkan jumlah kunjungan wisatwan domestik dan wisatawan mancanegara, untuk meningkatkan kesejahteraan dan pendapatan masyarakat lokal yang berdampak pada peningkatan Pendapatan Asli Daerah (PAD).

Festival parade Pesona Kebangsaan diisi dengan berbagai acara atau kegiatan yang telah disiapkan dan dikoordinir oleh Dinas Pariwisata Kabupaten Ende. Berbagai macam acara tersebut dibuat untuk mengisi rangkaian kegiatan selama festival ini berlangsung. Bentuk kegiatannya yakni: Pagelaran Budaya Nusantara, Fun Bike, Lomba Hiking, Ende Expo, Parade laut dan parade darat. Kegiatan parade darat dilakukan dengan menyusuri rute yang sudah ditentukan dan menyusuri napak tilas jejak sejarah peninggalan Soekarno seperti KODIM 1602 Ende, Situs Rumah Pengasingan Bung Karno, Gedung Imakulata, Makam Ibu Amsi, Serambi Bung Karno, Pohon Sukun di Taman Bung Karno dan Lapangan Pancasila.

\section{Faktor-Faktor Yang Mempengaruhi Festival Parade Pesona Kebangsaan}

Ada beberapa faktor yang mendukung pelaksanaan festival tersebut yakni:

a. Potensi Objek Wisata

Kabupaten Ende memiliki banyak potensi wisata atau objek daya tarik wisata yang lengkap. Ada wisata alam, wisata budaya, wisata buatan dan wisata minat khusus. Potensi daya Tarik wisata di Kabupaten Ende yang sudah terdata 108 buah. Keragaman bentuk daya Tarik wisata tersebut menjadikan Kabupaten Ende sebagai kabupaten yang paling lengkap untuk jenis objek wisata dibandingkan dengan kabupaten lain.

\section{b. Sarana dan Prasarana}

Sarana dan prasarana di Kabupaten Ende sudah cukup banyak seperti hotel, penginapan, restoran, tempat hiburan dan lain sebagainya. Berdasarkan data yang dikeluarkan oleh BPS Kabupaten Ende tahun 2019, jumlah unit hotel dan penginapan yang ada di Kabupaten Ende berjumlah 58 Unit. Jumlah unit hotel dan penginapan tersebut, sebagian besar berada di daerah wisata Moni (Kelimutu).

c. Dukungan Kementerian dan Provinsi

Penyelenggaraan Festival Parade Pesona Kebangsaan mendapat banyak dukungan yang berasal dari Kementerian Pariwisata dan Pemerintahan Provinsi Nusa Tenggara Timur. Bentuk dukungannya lewat bantuan media promosi dll.

\section{d. Dukungan Elemen Masyarakat}

Pelaksanaan Event ini mendapat dukungan dari seluruh elemen masyarakat Kabupaten Ende. Melalui Event Festival Parade Pesona Kebangsaan, masyarakat Kabupaten Ende menjadi bangga akan identitas dirinya. Masyarakat menjadi bangga karena gagasan besar Pancasila lahir di bumi Ende.

Ada pun faktor -faktor penghambat Festival Parade Pesona Kebangsaan ialah:

a. Anggaran

Data anggaran dari Rencana Kerja dan Anggaran (RKA) tahun 2019 Dinas Pariwisata Kabupaten Ende menunjukkan bahwa anggaran untuk pelaksanaan event promosi wisata tahun 2019 sebesar Rp. 164.250.000 (Seratus Enam Puluh Empat Juta Dua Ratus Lima Puluh Ribu Rupiah). Jumlah dana tersebut digunakan untuk pelaksanaan dua event promosi wisata di Kabupaten Ende yakni Festival Parade Pesona kebangsaan dan Festival Kelimutu. Sekitar 60 \% anggaran 
tersebut digunakan untuk pelaksanaan Festival Parade Pesona Kebangsaan dan 40\% dianggarkan untuk pelaksanaan Festival Kelimutu. Untuk event pariwisata berskala nasional, anggaran yang direncanakan tersebut sangat kecil.

b. Sumber Daya Masyarakat

Masyarakat selaku subjek pelaku pariwisata dan objek dari pariwisata perlu menyadari bahwa pariwisata merupakan salah satu industri jasa berkembang yang tidak memerlukan banyak modal namun dapat mendatangkan keuntungan untuk menambah jumlah pendapatan masyarakat. Hal ini menjadi suatu masalah karena masyarakat belum sepenuhnya memiliki kesadaran atau memiliki rasa sadar wisata. Pada akhirnya out put dari setiap penyelenggaraan event belum sepenuhnya menyentuh semua elemen masyarakat. Dampak yang terjadi ialah pelayanan wisata di lapangan cenderung kurang maksimal.

\section{Strategi Promosi Festival Parade Pesona Kebangsaan}

Festival Parade Pesona Kebangsaan adalah sebuah strategi promosi yang menawarkan produk wisata Kabupaten Ende atau atraksi wisata atau dengan kata lain memberi penawaran lain berupa daya tarik wisata Kabupaten Ende kepada wisatawan. Strategi promosi Event Festival Parade Pesona Kebangsaan Dinas Pariwisata Kabupaten Ende akan ditelaah dalam pembahasan mengenai keenam elemen utama promosi ini.

a. Personal Selling (Penjualan Perorangan)

Hasil penelitian menunjukkan bahwa upaya promosi melalui kegiatan personal selling masih belum dilakukan oleh Dinas Pariwisata Kabupaten Ende. Upaya promosi lewat personal selling justru dilakukan oleh pihak lain. Dinas Pariwisata Kabupaten Ende mengharapkan agen travel yang membuat paket dan menjual langsung atau menawarkan kepada wisatawan yang akan datang ke Ende dan menjelaskan kepada wisatawan. Fakta ini menunjukkan ada keterbatasan persiapan dari Dinas Pariwisata. Di lain pihak, pihak agen travel merasa kebingungan dengan sikap dari Dinas Pariwisata. Pihak Dinas Pariwisata terkesan membuat event berskala nasional ini dalam waktu yang mepet atau singkat sehingga pihak agent travel merasa kesulitan untuk menjual paket wisata tersebut apalagi terkait event festival.

b. Advertising (Iklan)

Berdasarkan fenomena yang peneliti temukan di dalam penelitian ini diketahui bahwa promosi Festival Parade Pesona Kebangsaan sudah dilakukan lewat media iklan namun belum maksimal. Upaya promosi yang dibuat adalah lewat iklan di radio daerah. Iklan tidak seepenuhnya dilakukan secara masif namun menggunakan media lokal yang ada. Radio lokal daerah hanya bisa mencakup pendengar yang berada di wilayah Kabupaten Ende dan tidak semua masyarakat mendengar radio dan mengetahui event tersebut. Pemanfaatan media-media periklanan (advertising) yang dapat dilihat langsung oleh masyarakat dan media iklan yang digunakan seharusnya bisa menjangkau level nasional lewat media-media yang berskala nasional.

c. Sales Promotion (Promosi Penjualan)

Upaya promosi penjualan (sales promotion) tidak sepenuhnya dilakukan oleh Dinas Pariwisata Kabupaten Ende dalam memperkenalkan potensi wisata Ende. Dinas Pariwisata masih belum mampu mempopulerkan event festival ini secara nasional. Upaya pelaksanaan promosi penjualan terkendala masalah keuangan atau anggaran untuk promosi. Dinas Pariwisata belum mampu menemukan satu cara lain atau alternatif lain yang bisa digunakan untuk melakukan promosi penjualan.

d. Publicity (Publisitas) 
Berdasarkan hasil temuan, Dinas Pariwisata Kabupaten Ende memperoleh cara promosi lewat publisitas atau publikasi yang dilakukan oleh pihak Garuda Indonesia. Publikasi terkait event ini dimasukkan di dalam majalah Garuda Indonesia guna memberikan seluruh informasi terkait seluruh kegiatan festival tersebut. Publikasi lewat majalah Garuda Indonesia ini sudah tidak lagi berlangsung oleh karena pesawat Garuda Indonesia sudah tidak lagi membuka rute penerbangan menuju Ende.

e. Sponsorship Marketing (Pemasaran Sponsor)

Dari hasil penelitian, Dinas Pariwisata Kabupaten Ende belum pernah sekalipun melakukan upaya sponsorship marketing. Pihak Dinas Pariwisata Kabupaten Ende tidak memahami dengan jelas pemahaman terkait sponsorship berkenaan dengan promosi wisata daerah. Fakta yang dihadapi ialah upaya promosi ini belum pernah dilaksanakan karena memang terbatas oleh biaya atau anggaran untuk melakukan hal tersebut.

f. Point of Purchase Communication (Komunikasi di tempat pembelian)

Dinas Pariwisata Kabupaten Ende melakukan upaya komunikasi langsung terkait pariwisata di tempat pembelian pada saat acara di JCC atau pada kesempatan menghadiri promosi wisata di Jakarta Convention Centre 2 tahun lalu. Hal ini dilakukan pertama dan terakhir kali sudah dua tahun lalu.

Berdasarkan hasil penelitan terkait strategi promosi wisata lewat Festival Parade Pesona Kebangsaan, ditemukan bahwa Dinas Pariwisata Kabupaten Ende belum sepenuhnya menjalankan upaya atau strategi promosi berdasarkan kriteria bauran promosi (Mix Promotion).

\section{Reformulasi Strategi Promosi Festival Parade Pesona Kebangsaan}

Strategi promosi wisata Festival Parade Pesona Kebangsaan mengarah ke arah positif karena event promosi tersebut cukup memberikan dampak bagus untuk pariwisata di Kabupaten Ende meskipun tidak terlalu signifikan perkembangannya. Festival Parade Pesona Kebangsaan masih dapat bertumbuh dan berkembang menjadi sebuah event promosi yang lebih menarik dan dikenal banyak orang. Promosi pariwisata semacam ini memerlukan strategi yang lebih intensif. Strategi yang bisa diterapkan yakni pengembangan pasar promosi wisata dan inovasi produk wisata.

\section{a. Pengembangan Pasar Promosi Wisata}

Pengembangan pasar promosi wisata merupakan suatu cara yang dilakukan untuk memperluasan pasar promosi ke arah yang lebih luas dan besar. Upaya pengembangan pasar promosi ini dilakukan dengan cara mencari pasar baru untuk memperomosikan produk wisata. Produk wisata dipromosikan dan diperkenalkan di tempat-tempat atau daerah-daerah baru yang belum sepenuhnya mengenal tentang produk wisata yang ditawarkan. Sehingga pasar promosi wisata Kabupaten Ende tidak selalu mengandalkan promosi dari Jakarta dan Bali. Oleh karena itu, untuk mencapai target tersebut maka, upaya-upaya promosi harus dilakukan secara lebih efektif dan efisien. Upaya strategi promosi yang efektif dan efisien mengindikasikan meminimalisir penggunaan dana yang besar dan tenaga yang banyak. Upaya promosi wisata yang bisa dilakukan ialah:

\section{b. Pembuatan Iklan Yang Masif Dan Selektif}

Pembuatan iklan yang masif diupayakan dengan pemanfaatan media baik elektronik maupun massa atau pun media online. Iklan yang masif ini tentu harus dipilih secara selektif dengan media-media yang bisa dipercayai dan diajak untuk bekerja sama. Untuk media cetak bisa dilakukan kerja sama dengan majalah-majalah penerbangan seperti majalah Lion Air, 
majalah Trans Nusa dan majalah Sriwijaya Air serta majalah Garuda Indonesia. Majalah maskapai penerbangan tersebut dipilih karena maskapai ini menjangkau seluruh wilayah di Indonesia dan luar negeri.

c. Promosi Penjualan Yang Kreatif

Bentuk promosi yang kreatif harus dibuat semenarik mungkin dan memberikan kemudahan bagi wisatawan. Promosi penjualan yang bisa dilakukan yakni penggunaan flashdisk yang diberikan secara gratis kepada setiap wisatawan lokal maupun mancanegara. Flashdisk tersebut berisi foto-foto objek wisata dan segala informasi terkait objek wisata tersebut. Ada juga video-video pendek berisi keindahan objek wisata dan atraksi wisata baik alam, budaya dan bahari yang ada di Kabupaten Ende.

d. Personal Selling Yang Intens

Personal selling bisa dilakukan dengan menjalin kerja sama dengan organisasi-organisasi yang ada dan mengajak mereka untuk ikut terlibat. Dinas Pariwisata Kabupaten Ende dapat mengajak organisasi-organisasi anak muda, dengan memanfaatkan tenaga dan waktu yang dimiliki oleh organisasi-organisasi tersebut. Semua pihak dilibatkan berkat kerja sama tersebut dan ada pelatihan khusus untuk mereka terkait pariwisata dan wisatawan.

e. Komunikasi Di Tempat Pembelian Yang Menarik

Strategi promosi melalui komunikasi di tempat pembelian yang menarik merujuk kepada pengunaan media display atau poster yang didesain semenarik mungkin agar menarik minat wisatawan. Tempat pembelian yang dimaksud bisa terjadi pada toko cinderamata atau oleholeh khas daerah.

\section{f. Inovasi Produk Wisata}

Berbicara tentang produk wisata, tentu tidak terlepas dari paket wisata. Dinas Pariwisata Kabupaten Ende dapat lebih aktif untuk melibatkan seluruh agen travel untuk membuat paket wisata yang lebih kreatif dan inovatif. Paket wisata yang dibuat tidak monoton dan sama satu sama lainnya. Tapi paket wisata dibuat dapat lebih beragam dengan segala bentuk tawaran paket berdasarkan segmen pasar. Sebagai contoh, agen travel dapat membuat paket wisata untuk pasar domestik dan mancanegra, paket wisata untuk mahasiswa atau anak sekolah, paket honeymoon, paket event budaya, paket-paket wisata agrotourism dan lain sebagainya serta dibuat dengan harga yang menarik dan terjangkau.

\section{Implikasi Strategi Promosi Festival Parade Pesona Kebangsaan}

Strategi Promosi Festival Parade Pesona Kebangsaan membutuhkan penerapan langkah-langkah baru. Implikasi strategis dalam upaya promosi yang bisa diterapkan oleh dinas pariwisata kabupaten Ende selanjutnya adalah:

a. Promosi Kreatif (Creative Promotion)

Strategi promosi perlu didukung juga oleh beberapa kegiatan lanjutan terkait pariwisata sehingga promosi tidak hanya dilakukan ketika ada undangan atau ada anggaran yang besar. Beberapa kegiatan promosi wisata dalam tingkat lokal kedaerahan juga bisa dilakukan dengan tujuan untuk memberi pemahaman kepada masyarakat lokal terkait pariwisata, diantaranya:

14 | Barista: Jurnal Kajian Bahasa dan Pariwisata, Volume 6 Nomor 1, 2019: 8-16 
lewat dialog pariwisata, karya wisata untuk anak sekolah, mengikuti pameran wisata daerah dan membuat atraksi wisata tambahan di lokasi objek wisata.

b. Kemitraan Strategis (Strategic Partnership)

Kemitraan strategis dapat diupayakan oleh Dinas Pariwisata Kabupaten Ende dengan pihakpihak yang selama ini mendukung pengembangan pariwisata daerah. Dinas Pariwisata Kabupaten Ende bisa menjalin kerja sama dan melibatkan agen travel perjalanan, komunitaskomunitas photography dan youtuber, para blogger, pengamat budaya, para seniman, POKDARWIS serta kelompok-kelopok anak muda lainnya.

c. Paket Dan Program (Packaging and programming)

Dinas Pariwisata Kabupaten Ende bisa membuat suatu program wisata yang menarik dan variatif terkait wisata di kabupaten Ende. Selain menjalin kerja sama dengan agen travel dalam pembuatan paket wisata, Dinas Pariwisata Kabupaten Ende juga bisa membuat suatu program khusus. Program yang menarik wisatawan yang bisa dilakukan yakni program city tour. Paket wisata city tour ini hanya menjangkau objek-objek wisata yang ada di seputaran kota Ende.

\section{SIMPULAN}

Kabupaten Ende mempunyai banyak macam potensi wisata berupa wisata alam, wisata budaya, wisata bahari dan wisata buatan. Potensi wisata tersebut merupakan modal dasar dalam pengembangan pariwisata. Pariwisata menjadi salah satu program pemerintah daerah Kabupaten Ende dalam meningkatkan kunjungan wisatawan, peningkatan pendapatan Asli Daerah (PAD) dan mensejahterahkan masyarakat lokal. Pariwisata daerah dengan berbagai potensi wisatanya diperkernalkan dan ditawarkan kepada wisatawan dengan cara melakukan promosi wisata. Promosi wisata merupakan salah satu cara yang dilakukan untuk memberitahu, menginformasikan, menawarkan dan mempengaruhi masyarakat dan wisatawan tentang potensi wisata yang ada di Kabupaten Ende.

Salah satu strategi promosi wisata yang dilakukan ialah lewat pelaksanaan Festival Parade Pesona Kebangsaan yang diadakan setiap tahun. Ada beberapa faktor yang mendukung dan menghambat dalam proses pencapaian tujuan dari pelaksanaan festival Parade Pesona Kebangsaan. Faktor faktor pendukung dan penghambat pencapaian tujuan dari pelaksanaan event promosi tersebut menjadi sebuah persoalan klasik yang dihadapi oleh pemerintah daerah. Pemerintah daerah melalui Dinas Pariwisata Kabupaten Ende berupaya mempromosikan potensi wisatanya namun masih banyak kendala yang muncul terkait dukungan anggaran dan kesiapan sumber daya masayarakat terkait pengelolaan dan pengembangan pariwisata. Strategi promosi wisata di Kabupaten Ende bisa dilakukan berdasarkan langkah-langkah promosi yang lebih efektif dan efisien sehingga tujuan dari pelaksanaan festival dapat tercapai dan mendukung pengembangan pariwisata di Kabupaten Ende.

\section{DAFTAR PUSTAKA}

Badan Pusat Statistik. (2019). Kabupaten Ende Dalam Angka 2019. Ende: Badan Pusat Statistik Kabupaten Ende.

Harris, B. M. (1985). Supervisory Behavior in Education. New Jersey: Prentice Hall.

Jiunkpe. (1998). Time Out of Time. Essay On the Festival Falasi, Indonesia.

Kotler, P. (1999). Marketing dalam Terjemahan Bahasa Indonesia. Jakarta: Erlangga.

Keller, Kevin L. dan Kotler, P. (2009). Manajemen Pemasaran. Edisi 13. Jilid 2. Jakarta: PT. Indeks

Kristanto, V., H. (2018). Metodologi Penelitian Pedoman Penulisan Karya Tulis Ilmiah (KTI). Yogyakarta: CV. Budi Utama. 
Lehmann, H. (1990). The Systems Approach to Education. Special Presentation Conveyed in The International Seminar on Educational Innovation and Technology Manila. Innotech Publications, Vol 20, No. 05.

Pearce, J., A. \& Robinson, R., B. (2008). Manajemen Strategis. Jakarta: Salemba Empat

Sugiyono. (2013). Metode Penelitian Kuantitatif Kualitatif. Bandung: Alfabeta

Susanti, R., Damanik, J., \& Priyambodo, T. K. (2017). Organization of Sport Tourism Event Tour de Singkarak Contribution Toward Tourist Attraction Improvement in West Sumatra. Journal of Humanities and Social Science, Volume 22, Pp.1-13.

Tayibnapis, F., Y. (2000). Evaluasi Program. Jakarta: Rineka Cipta.

Tobing, D., H. et al. (2016). Metode Penelitian Kualitatif. Bali: Universitas Udayana.

Yusuf, M. (2014). Metode Penelitian Kuantitatif, Kualitatif dan Penelitian Gabungan. Jakarta: Kencana. 